\title{
Reaction Kinetics of Ammonium Removal from Cow Urine by Struvite Formation Using a Baffle Column Reactor
}

\section{Kinetika Reaksi Penyisihan Amonium dari Urine Sapi dengan Pembentukan Struvite Menggunakan Reaktor Kolom Bersekat}

\author{
Rizqi Rendri Anggriawan a,1, Fauziah Hilda Alvira a,2, Luluk Edahwati a,3,* \\ a Program Studi Teknik Kimia, Fakultas Teknik, Universitas Pembangunan Nasional “Veteran” Jawa Timur, Jl Rungkut Madya 1 Surabaya 60294, \\ Indonesia \\ ${ }^{1}$ rrendrianggriawan24@gmail.com; ${ }^{2}$ fauziahhilda11@gmail.com; ${ }^{3}$ lulukedahwati@gmail.com* \\ * corresponding author
}

ARTICLE INFO

Article history

Received October 16, 2020

Revised November 26, 2020

Accepted January 14, 2021

Keywords

Ammonium removal

Baffle column reactor

Cow urine

Kinetic reaction

Struvite

\section{ABSTRACT}

Reaction kinetics is the study of reaction rates and reaction mechanisms, which refers to determining the order and reaction rate constants of a given material. This study will examine the kinetics of the reaction of ammonium removal from cow urine by struvite formation. Cow urine contains $\mathrm{NH}_{4}$ which is high enough so that it can be used as material for the manufacture of struvite. Struvite $\left(\mathrm{MgNH}_{4} \mathrm{PO}_{4} .6 \mathrm{H}_{2} \mathrm{O}\right)$ is a white crystalline material consisting of magnesium, ammonium, and phosphate in equimolar. The experiment was conducted with a temperature setting of $25,35,45$, and $65{ }^{\circ} \mathrm{C}$. The flow rates used were $8.8,11,14.67,22$, and $44 \mathrm{~mL} / \mathrm{min}$. The process of making struvite was carried out by crystallization at $\mathrm{pH} 9$, molar ratio of $3: 1: 1$, also air rate of $0.4 \mathrm{~L} / \mathrm{min}$. The study carried out following the first order with the best conversion was 0.7797 at 8.8 $\mathrm{ml} / \mathrm{min}$ and $65{ }^{\circ} \mathrm{C}$. The activation energy is $3123.82 \mathrm{~J} / \mathrm{mol}$ and collision frequency is 0.0379 . The equation of reaction rate $k=$ $0.0379 e^{-375,73 / T}\left(K^{-1}\right)$.

This is an open access article under the CC-BY-SA license.

\section{Pendahuluan}

Keberadaan senyawa amonium pada limbah urine sapi dapat menyebabkan permasalahan lingkungan yang serius [1]. Untuk mengurangi kadar amonium yang terkandung pada urine sapi, maka kita dapat memanfaatkan keberadaan senyawa tersebut dengan mengonversi senyawa tersebut menjadi produk yang berharga. Kadar amonium pada limbah urine sapi adalah 4580,98 mg/L. Dari kandungan amoniumnya, urine sapi dapat dimanfaatkan sebagai struvite [2]. Struvite merupakan mineral berwarna putih yang terbentuk dari magnesium, amonium, dan fosfat dengan rasio molar yang sama. Rumus molekul struvite adalah $\mathrm{MgNH}_{4} \mathrm{PO}_{4} \cdot 6 \mathrm{H}_{2} \mathrm{O}$. Morfologi dari struvite adalah kristal ortorombik [3]. Struvite memiliki kemampuan slow release yakni lepas lambat [4].

Pembentukan kristal struvite dilakukan dengan cara kristalisasi. Dimana pada pembentukan kristal struvite akan terjadi pembentukan inti kristal dan pertumbuhan kristal [5]. Pada proses pembentukan struvite, digunakan alat yang mampu menyisihkan amonium sebanyak mungkin, sehingga amonium pada urine sapi dapat ter-recover menjadi struvite. Penyisihan amonium menggunakan reaktor berpengaduk perlu dihindari, struvite yang terbentuk akan menempel pada pengaduk dan menyebabkan kristal struvite rentan memiliki bentuk yang tidak beraturan akibat pergerakan/tumbukan kristal dengan pengaduk [6]. Sehingga penggunaan pengaduk dapat diganti dengan penambahan gelembung udara (aerasi). Aerasi bertujuan untuk mempercepat proses 
pembebasan sejumlah amonium terlarut dari limbah [7]. Reaktor kolom bersekat merupakan alat yang menggunakan laju udara sebagai pengganti pengaduk. Reaktor ini disertai dengan sekat yang berfungsi untuk memecah gelembung udara yang berukuran besar sehingga gelembung udara memiliki ukuran seragam.

Kinetika reaksi merupakan ilmu kimia yang mempelajari tentang laju reaksi dan mekanisme reaksi. Kinetika reaksi mengacu pada penentuan orde reaksi dan tetapan laju reaksi dari material yang ditentukan. Selain menentukan orde reaksi dan tetapan laju reaksi, penelitian ini juga dilakukan untuk menentukan energi aktivasi [8]. Dalam penelitian kali ini, peneliti akan mengkaji kinetika reaksi yang terjadi dalam penyisihan amonium pada limbah urine sapi sebagai mineral struvite. Penelitian mengenai kinetika reaksi struvite telah dilakukan sebelumnya menggunakan reaktor berpengaduk yang mengikuti orde satu [9].

\subsection{Orde Satu}

Dalam penentuan orde satu, reaksi dianggap $\mathrm{A} \rightarrow \mathrm{R}$, dimana A adalah reaktan amonium dan $\mathrm{R}$ adalah produk struvite. Persamaan laju reaksinya adalah sebagai berikut :

$$
-r_{A}=-\frac{d c_{A}}{d t}=k C_{A}
$$

Persamaan (1) diintegralkan sehingga menjadi :

$$
-\ln \left[C_{A}\right]+\ln \left[C_{A}\right]_{0}=k t
$$

\subsection{Orde Dua}

Dalam penentuan orde dua, reaksinya adalah $\mathrm{A}+\mathrm{B}+\mathrm{C} \rightarrow \mathrm{R}$, dimana $\mathrm{A}$ adalah reaktan amonium, $\mathrm{B}$ adalah reaktan fosfat, $\mathrm{C}$ adalah reaktan magnesium, dan $\mathrm{R}$ adalah produk struvite. Karena konsentrasi reaktan $\mathrm{C}$ sangat besar, maka konsentrasi tiap waktunya dianggap konstan. Reaktan A dan B memiliki konsentrasi yang sama (equimolar). Sehingga reaksi dianggap $2 \mathrm{~A} \rightarrow \mathrm{R}$ Persamaan laju reaksinya adalah sebagai berikut :

$$
-r_{A}=-\frac{d c_{A}}{d t}=k C_{A}^{2}
$$

Persamaan (3) diintegralkan sehingga menjadi :

$$
\frac{1}{\left[C_{A}\right]}-\frac{1}{\left[C_{A}\right]_{0}}=k t
$$

\subsection{Hubungan Laju Alir dan Waktu Tinggal}

Waktu tinggal (residence time) adalah waktu yang diperlukan untuk mereaksikan zat reaktan di dalam reaktor alir. Untuk sistem densitas konstan, maka waktu rata-rata sama dengan waktu tinggal, seperti ditunjukkan pada persamaan berikut ini [8]:

$$
\underline{t}=t=\frac{v(\text { Volume Isian Reaktor })}{v \text { (laju alir umpan })}
$$

Studi pengaruh laju alir pada pembentukan struvite telah dilakukan sebelumnya. Laju alir umpan 16-38 mL/menit menghasilkan perolehan fosfat hingga 37,19\% [10]. Pengaturan laju alir umpan dalam range 15-40 mL/menit menghasilkan konversi struvite sebesar 0,007767-0,01889\% [11]. Sesuai dengan persamaan (5), laju alir umpan berbanding terbalik dengan waktu tinggal. Sehingga semakin besar laju alir, maka semakin sedikit waktu tinggal reaktan di dalam reaktor.

\section{Metodologi}

\subsection{Bahan}

Bahan yang digunakan adalah limbah urine sapi sebagai sumber amonium $\left(\mathrm{NH}_{4}\right)$ yang diambil dari peternakan sapi di Balongpanggang, Gresik. Adapun bahan lainnya adalah magnesium klorida teknis $\left(98 \%\right.$ flakes $\left.-\mathrm{MgCl}_{2}\right)$ sebagai sumber magnesium $(\mathrm{Mg})$, asam fosfat $\left(85 \% \mathrm{H}_{3} \mathrm{PO}_{4}\right)$ sebagai sumber fosfat $\left(\mathrm{PO}_{4}\right)$, dan kalium hidroksida teknis $(90 \%$ flakes- $\mathrm{KOH})$ konsentrasi $1 \mathrm{~N}$ sebagai pengatur $\mathrm{pH}$, dimana ketiga bahan kimia ini dibeli di Bratachem.

\subsection{Prosedur}

Larutan MAP (magnesium amonium fosfat) dibuat dengan perbandingan rasio molar 3:1:1. Reaktor dengan volume 498,75 mL diisi larutan MAP hingga mencapai 3/4 ketinggian reaktor. 
Pemanas diatur dengan variasi suhu 25, 35, 45, 55, dan $65^{\circ} \mathrm{C}$. Skema Reaktor Kolom Bersekat disajikan pada Gambar 1. Kran laju alir MAP dibuka dengan variasi laju alir 8,8; 11; 14,67; 22; dan $44 \mathrm{~mL} /$ menit. Kran udara masuk diatur sebesar 0,4 L/menit. Kran MAP dan $\mathrm{KOH}$ diatur dengan perbandingan laju alir sebesar 3:1. Kedua larutan akan membentuk kristal struvite pada pH 9 dan larutan akan menuju tangki penampung larutan keluar. Larutan dianalisa untuk mengetahui kandungan amoniumnya (spektrofotometri) dan endapan dianalisa XRD.

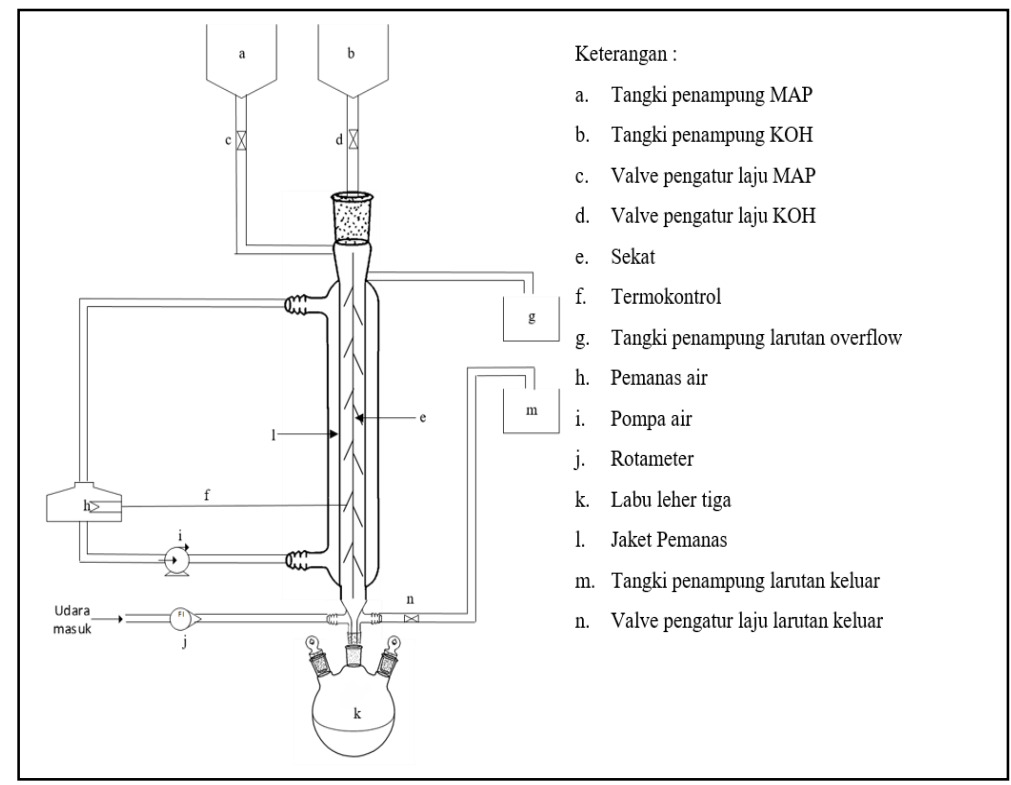

Gambar 1. Reaktor Kolom Bersekat

\subsection{Metode Perhitungan}

Untuk menentukan kinetika reaksi diperlukan data konsentrasi awal dan akhir pada satu kali proses berlangsungnya reaksi. Reaksi pembentukan struvite dalam penelitian ini adalah sebagai berikut:

$$
\mathrm{MgCl}_{2(\mathrm{~s})}+\mathrm{H}_{3} \mathrm{PO}_{4(\mathrm{aq})}+\mathrm{NH}_{4}{ }^{+}{ }_{\text {(aq })}+6 \mathrm{H}_{2} \mathrm{O} \rightarrow \mathrm{MgNH}_{4} \mathrm{PO}_{4} \cdot 6 \mathrm{H}_{2} \mathrm{O}_{(\mathrm{s})}+2 \mathrm{HCl}_{(\mathrm{aq})}+\mathrm{H}^{+}{ }_{(\mathrm{aq})}
$$

Kinetika reaksi penyisihan amonium dapat dilakukan dengan menggunakan dua pendekatan yakni orde satu dan orde dua. Formula untuk menentukan kinetika ditunjukkan pada Tabel 1 [12].

Tabel 1. Model perhitungan yang dipakai

\begin{tabular}{ccc}
\hline Model & Formula \\
\hline Orde satu & $\ln \ln \left[C_{A}\right]=-k t+\ln \ln \left[C_{A}\right]_{0}$ \\
Orde dua & $\frac{1}{\left[C_{A}\right]}=k t+\frac{1}{\left[C_{A}\right]_{0}}$ \\
Persamaan Arrhenius & $\ln \ln k=\ln \ln k_{0}-\frac{E}{R T}$ \\
\hline
\end{tabular}

\section{Hasil dan Pembahasan}

Hasil penelitian dimana variabel yang dijalankan meliputi laju alir (v) dan suhu (T). Dengan persamaan 5, maka laju alir dapat dikonversi menjadi waktu tinggal (menit) dengan pembagian antara volume reaktor dan laju alir MAP. Data disajikan pada Tabel 2 dan Tabel 3.

Tabel 2. Penentuan waktu tinggal (menit) dari laju alir umpan (mL/menit)

\begin{tabular}{cc}
\hline Laju Alir, v (mL/menit) & Waktu tinggal, t (menit) \\
\hline 8,8 & 56.68 \\
11 & 45,34 \\
14,67 & 34 \\
22 & 22,67 \\
44 & 11,34 \\
\hline
\end{tabular}


Tabel 3. Pengaruh suhu dan waktu tinggal terhadap konsentrasi amonium setelah proses penyisihan $\left[\mathrm{C}_{\mathrm{A}}\right]$

\begin{tabular}{cccccc}
\hline \multirow{2}{*}{ Suhu $\left({ }^{\circ} \mathbf{C}\right)$} & \multicolumn{5}{c}{$\left[\mathbf{C}_{\mathbf{A}}\right](\mathbf{m o l} / \mathbf{L})$} \\
\cline { 2 - 5 } & $\mathbf{1 1 , 3 4}$ & $\mathbf{2 2 , 6 7}$ & $\mathbf{3 4}$ & $\mathbf{4 5 , 3 4}$ & $\mathbf{5 6 , 6 8}$ \\
\cline { 2 - 6 } & 0,1135 & 0,0989 & 0,0834 & 0,0818 & 0,0673 \\
35 & 0,1120 & 0,0932 & 0,0817 & 0,0799 & 0,0652 \\
45 & 0,1057 & 0,0926 & 0,0809 & 0,0703 & 0,0621 \\
55 & 0,1025 & 0,0917 & 0,0798 & 0,0702 & 0,0589 \\
65 & 0,1024 & 0,0852 & 0,0733 & 0,0697 & 0,0559 \\
\hline
\end{tabular}

Dari Tabel 3 terlihat semakin lama waktu tinggal larutan di dalam reaktor maka konsentrasi amonium pada larutan semakin kecil, hal ini disebabkan karena semakin lama kontak antar reaktan menyebabkan amonium semakin banyak yang terkonversi menjadi struvite. Dengan kata lain, semakin sedikit amonium yang tersisa di dalam limbah urin sapi. Hal ini selaras dengan penelitian sebelumnya dimana lamanya waktu pada penyisihan amonium menghasilkan 30\%-75\% amonium tersisih pada waktu 1-2 jam [13]. Adapun pengaruh suhu pada penyisihan amonium sebenarnya tidak memiliki pengaruh yang cukup signifikan akan tetapi penyisihan yang didapatkan akan cenderung naik seiring dengan meningkatnya suhu [14]. Disamping itu, energi kinetik partikel di dalam larutan akan semakin besar dengan banyaknya tumbukan dikarenakan suhu yang meningkat [15]. Pengaruh suhu pada penyisihan amonium telah sesuai dengan teori.

\subsection{Penentuan Orde Reaksi}

Orde reaksi dapat ditentukan dengan pendekatan orde reaksi satu dan dua. Dari kedua orde ini dicari persamaan garis lurus dengan nilai koefisien relasi $\left(\mathrm{R}^{2}\right)$ yang mendekati $1[8,16]$. Dalam menentukan orde reaksi satu dengan membuat grafik $\ln \left[\mathrm{C}_{\mathrm{A}}\right]$ versus $\mathrm{t}$ seperti yang ditunjukkan pada Gambar 2, sehingga didapatkan grafik berupa garis lurus dengan slope adalah nilai dari tetapan laju reaksi $(\mathrm{k})$ dan intercept adalah $\ln \left[\mathrm{C}_{\mathrm{A}}\right]_{0}$. Pada orde satu, nilai koefisien korelasi $\left(\mathrm{R}^{2}\right)$ yang didapatkan dalam rentang 0,9532-0,9997. Untuk orde dua dapat dilakukan dengan membuat grafik $1 /\left[\mathrm{C}_{\mathrm{A}}\right]$ versus t pada Gambar 3, maka didapat grafik berupa garis lurus dengan slope adalah tetapan laju reaksi (k) dan intercept adalah $1 /\left[\mathrm{C}_{\mathrm{A}}\right]_{0}$. Nilai $\mathrm{R}^{2}$ pada orde dua adalah $0,9482-0,9948$.

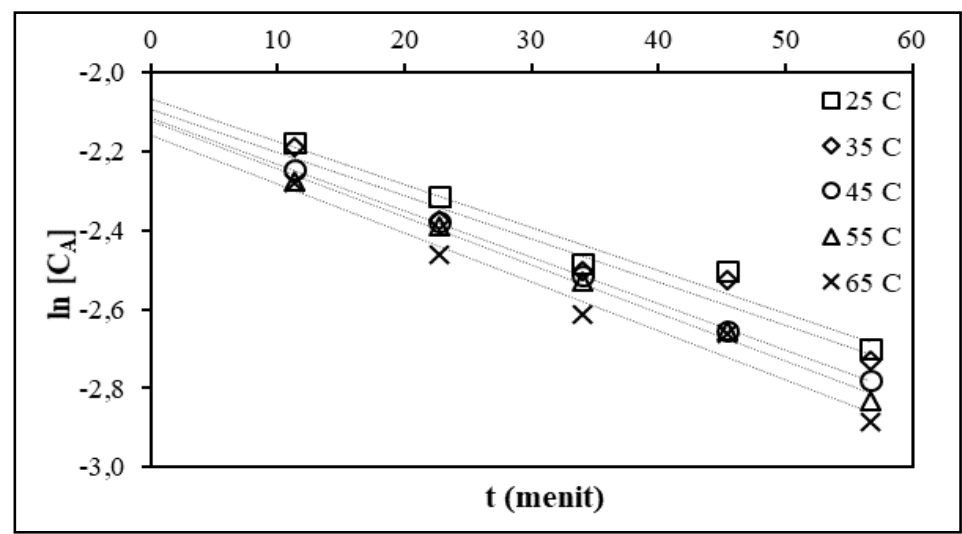

Gambar 2. Grafik hubungan antara $\ln \left[\mathrm{C}_{\mathrm{A}}\right]$ vs $\mathrm{t}$ (menit) untuk orde satu

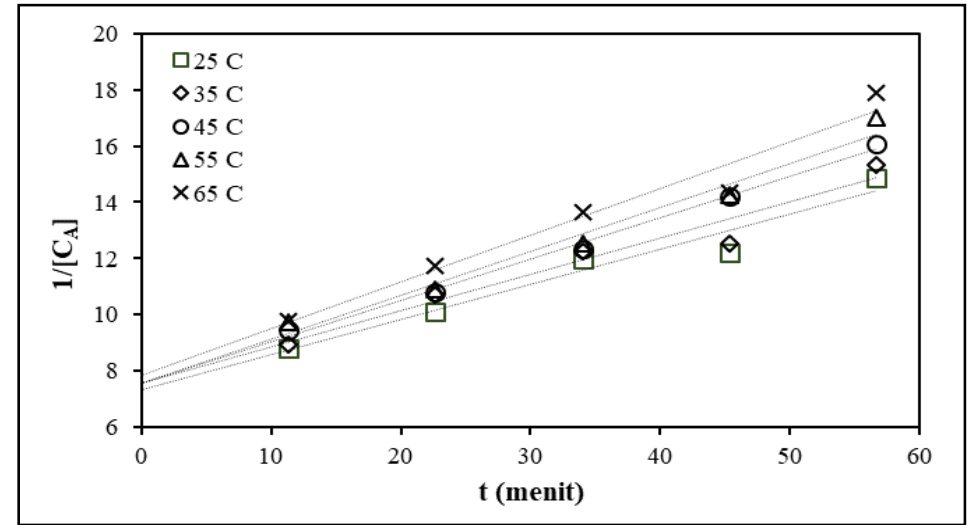

Gambar 3. Grafik hubungan antara $1 /\left[\mathrm{C}_{\mathrm{A}}\right]$ vs $\mathrm{t}$ (menit) untuk orde dua 
Nilai koefisien korelasi $\left(\mathrm{R}^{2}\right)$ pada penentuan orde 1 lebih mendekati 1 daripada pada orde 2 . Sesuai dengan persamaan (1), dimana terdapat satu reaktan yang berpengaruh dalam penentuan orde reaksi penelitian ini, yakni amonium. Sehingga kinetika reaksi penyisihan amonium pada limbah urine sapi dengan metode pembentukan struvite menggunakan reaktor kolom bersekat mengikuti orde satu yang membentuk persamaan garis lurus dengan nilai $\mathrm{R}^{2}$ yang paling mendekati 1 . Dalam hal ini, orde reaksi penelitian ini sama dengan penelitian-penelitian sebelumnya yang mengikuti orde reaksi satu $[17,18]$. Nilai tetapan laju reaksi disajikan pada Tabel 4, pada suhu 25, 35, 45, 55, dan $65^{\circ} \mathrm{C}$ berturut-turut adalah 0,$01089 ; 0,01091 ; 0,01179 ; 0,01214$; dan 0,01244 menit $^{-1}$. Sebagai perbandingan, tetapan laju reaksi penyisihan fosfat dengan metode pembentukan struvite sebesar 0,0096-0,0248 menit $^{-1}$ [18]. Penelitian lainnya mendapatkan nilai (k) sebesar 0,0037 menit ${ }^{-1}$ [17].

Tabel 4. Perbandingan persamaan dan koefisien korelasi $\left(\mathrm{R}^{2}\right)$ orde reaksi

\begin{tabular}{ccccc}
\hline \multirow{2}{*}{ Suhu $\left({ }^{\circ} \mathbf{C}\right)$} & \multicolumn{2}{c}{ Orde 1 } & \multicolumn{2}{c}{ Orde 2 } \\
\cline { 2 - 5 } & Persamaan & $\boldsymbol{R}^{\mathbf{2}}$ & Persamaan & $\boldsymbol{R}^{\mathbf{2}}$ \\
\hline 25 & $-0,01089 \mathrm{x}-2,0648$ & 0,9630 & $0,1253 \mathrm{x}+7,3378$ & 0,9541 \\
35 & $-0,01091 \mathrm{x}-2,0938$ & 0,9632 & $0,1829 \mathrm{x}+7,5669$ & 0,9482 \\
45 & $-0,01179 \mathrm{x}-2,1137$ & 0,9997 & $0,1471 \mathrm{x}+7,5826$ & 0,9948 \\
55 & $-0,01214 \mathrm{x}-2,1237$ & 0,9938 & $0,1571 \mathrm{x}+7,5417$ & 0,9747 \\
65 & $-0,01244 \mathrm{x}-2,1575$ & 0,9718 & $0,1662 \mathrm{x}+7,8250$ & 0,9601 \\
\hline
\end{tabular}

\subsection{Penentuan energi aktivasi, frekuensi tumbukan, dan persamaan tetapan laju reaksi}

Pada Gambar 4 menunjukkan grafik hubungan antara ln k vs 1/T. Dari Gambar 4 didapatkan persamaan dari hubungan antara $\ln (\mathrm{k})$ dengan $1 / \mathrm{T}$ adalah $\mathrm{y}=-375,73 \mathrm{x}-3,272$. Berdasarkan persamaan 9, didapatkan nilai $-\mathrm{E} / \mathrm{R}$ sebagai nilai slope sebesar $-375,73$ dan $\ln \mathrm{k}_{\mathrm{o}}$ sebagai intercept sebesar -3,272. Dengan memasukkan nilai konstanta gas ideal $\mathrm{R}=8,314 \mathrm{~J} / \mathrm{mol}$.K, sehingga energi aktivasi yang diperoleh adalah 3123,82 $\mathrm{J} / \mathrm{mol}$ sedangkan frekuensi tumbukan adalah 0,0379. Sehingga persamaan tetapan laju reaksi dengan mengikuti persamaan Arrhenius adalah sebagai berikut :

$$
k=0,0379 e^{-\frac{375,73}{T}}
$$

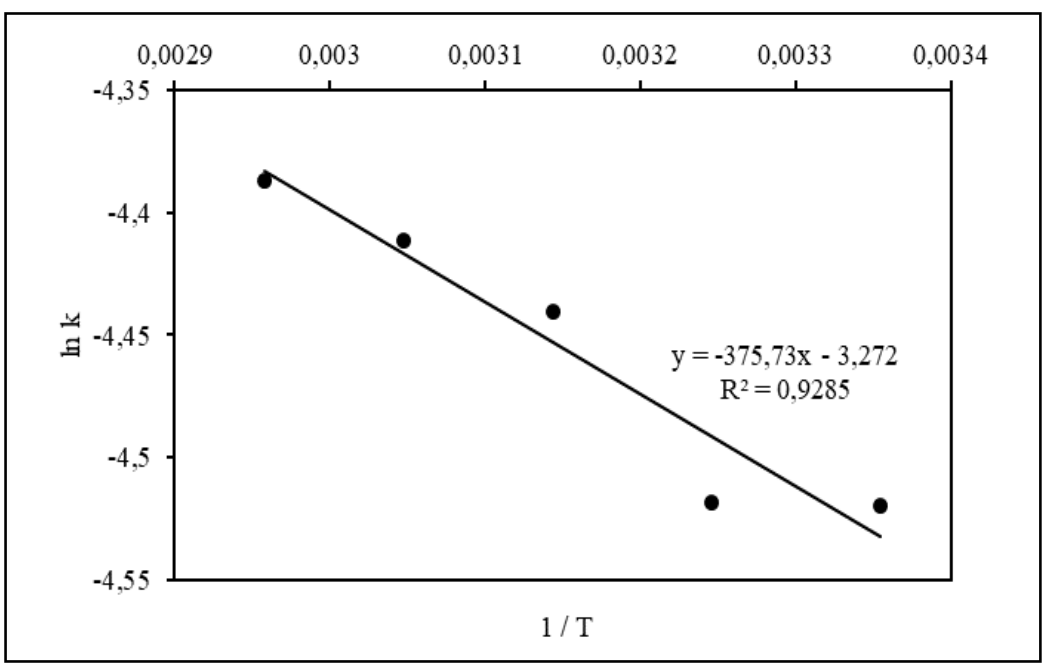

Gambar 4. Grafik hubungan antara ln k vs $1 / \mathrm{T}$

\subsection{Hasil XRD}

Komposisi kualitatif dari kristal dapat diidentifikasi dengan analisa XRD. Hasil XRD pada laju alir $8,8 \mathrm{~mL} /$ menit dan suhu $65{ }^{\circ} \mathrm{C}$ ditunjukkan pada Gambar 5 dapat dijelaskan bahwa material struvite telah terbentuk. Hal ini dibuktikan dengan cocoknya puncak grafik antara pola difraksi struvite (garis merah) dan sampel penelitian (garis biru). 


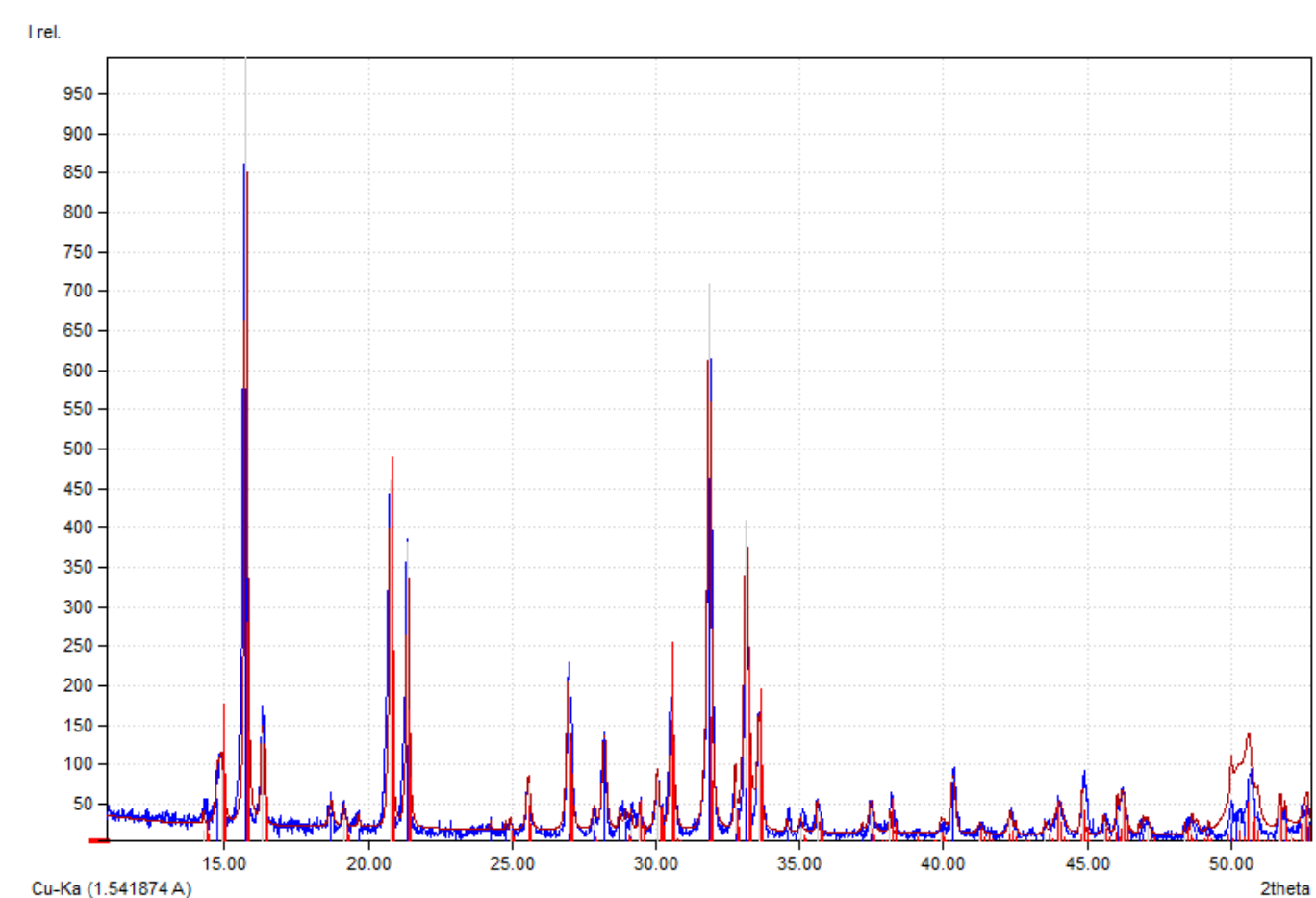

Gambar 5. Pola difraksi XRD sampel penelitian $8,8 \mathrm{~mL} / \mathrm{menit}-65^{\circ} \mathrm{C}$

\section{Kesimpulan}

Kinetika reaksi penyisihan amonium dari urine sapi dengan metode pembentukan struvite menggunakan reaktor kolom bersekat mengikuti orde satu dengan konversi terbaik pada suhu $65{ }^{\circ} \mathrm{C}$ dan laju alir $8,8 \mathrm{~mL} / \mathrm{menit}$ sebesar 0,7797 . Nilai tetapan laju reaksi pada suhu $25,35,45,55$, dan 65 ${ }^{\circ} \mathrm{C}$ berturut-turut adalah 0,$01089 ; 0,01091 ; 0,01179 ; 0,01214$; dan 0,01244 menit $^{-1}$. Nilai energi aktivasi sebesar 3123,82 J/mol sedangkan frekuensi tumbukan adalah 0,0379 . Persamaan tetapan laju reaksi adalah $\mathrm{k}=0,0379 \mathrm{e}^{-375,73 / \mathrm{T}}$

\section{Notasi}

$r_{A} \quad=$ laju reaksi, $\mathrm{mol} / \mathrm{L}$

$\left[C_{A}\right]=$ konsentrasi amonium setelah proses penyisihan, $\mathrm{mol} / \mathrm{L}$

$\left[C_{A}\right]_{O}=$ konsentrasi amonium sebelum proses penyisihan, $\mathrm{mol} / \mathrm{L}$

$t \quad=$ waktu tinggal, menit

$V \quad=$ volume reaktor, $\mathrm{mL}$

$v \quad=$ laju alir, $\mathrm{mL} / \mathrm{menit}$

$k \quad=$ tetapan laju reaksi orde 1 , menit ${ }^{-1}$

$k=$ tetapan laju reaksi orde $2, \mathrm{~L} \cdot \mathrm{mol}^{-1} \cdot$ menit $^{-1}$

$k_{o} \quad=$ frekuensi tumbukan, -

$E \quad=$ energi aktivasi, $\mathrm{J} / \mathrm{mol}$

$R \quad=$ konstanta gas ideal, $8,314 \mathrm{~J} / \mathrm{mol} . \mathrm{K}$

$T \quad=$ suhu, $\mathrm{K}$

\section{Ucapan Terimakasih}

Ucapan terima kasih dan penghargaan diberikan kepada Program Studi Teknik Kimia, Fakultas Teknik, Universitas Pembangunan Nasional "Veteran" Jawa Timur sebagai pihak yang memberikan bimbingan dan arahan pada penelitian ini.

\section{Daftar Pustaka}

[1] H. A. Aka, Suhendrayatna, and Syaubari, "Penurunan Kadar Amonia Dalam Limbah Cair Oleh Tanaman Air Typha Latifolia ( Tanaman Obor ),” J. Ilmu Kebencanaan, vol. 4, no. 3, pp. 72-75, 2017. 
[2] M. Prabhu and S. Mutnuri, "Cow Urine as a Potential Source for Struvite Production," Int J Recycl Orf Waste Agric., vol. 3, no. 49, pp. 1-12, 2014.

[3] M. I. Ali and Rajshahi, Struvite crystallization from nutrient rich wastewater. Johor: Thesis, University of Engineering and Technology (Bangladesh), MSc (Civil-Environment Engineering) University Technology Malaysia, 2005.

[4] T. M. F. Adiman, A. Feriyanto, . S., and L. Edahwati, "Mineral Struvite Dari Batuan Dolomit Dengan Reaktor Kolom Sekat," J. Tek. Kim., vol. 14, no. 2, pp. 85-91, 2020.

[5] C. J. Geankoplis, Transport Processes and Unit Operations Third Edition. New Jersey: Prentice Hall International, Inc, 1978.

[6] E. Ariyanto, Y. Niyati, D. Kharismadewi, and Robiah, "Kinetika Pembentukan Struvite Kristal Menggunakan Zeolit Alam sebagai Adsorben pada Aeration Cone Column Crystallizer," J. Rekayasa Proses, vol. 14, no. 1, pp. 60-73, 2020.

[7] L. Edahwati, Sutiyono, N. Zahra, and H. Septiani, "Magnesium Recovery of Struvite Formation Based on Waste Salts (Bittern) with a Bulkhead Reactor," Int. J. Eco-Innovation Sci. Eng., vol. 1, no. 01, pp. 1$5,2020$.

[8] O. Levenspiel, Chemical Reaction Engineering Third Edition. New York: John Wiley \& Sons, Inc., 1999.

[9] D. Crutchik and J. M. Garrido, "Kinetics of the reversible reaction of struvite crystallisation," Chemosphere, vol. 154, pp. 567-572, 2016.

[10] S. Sutiyono, L. Edahwati, S. Muryanto, Jamari, and A. P. Bayuseno, "Synthesis of Struvite using a Vertical Canted Reactor with Continuous Laminar Flow Process," in The 2nd International Joint Conference on Science and Technology (IJCST), 2018, pp. 1-5.

[11]L. Edahwati, Sutiyono, Jamari, and A. P. Bayuseno, "Kinetics Analysis of Synthesis Reaction of Struvite With Air-Flow Continous Vertical Reactors," in The 2nd International Joint Conference on Science and Technology (IJCST), 2018, pp. 1-6.

[12]J. M. Smith, Chemical Engineering Kinetics. McGraw Hill, Kogakusha Ltd., 1970.

[13]M. Türker and I. Çelen, "Removal of ammonia as struvite from anaerobic digester effluents and recycling of magnesium and phosphate," Bioresour. Technol., vol. 98, pp. 1529-1534, 2007.

[14] I. Çelen and M. Türker, "Recovery of ammonia as struvite from anaerobic digester effluents," Environ. Technol. (United Kingdom), vol. 22, no. 11, pp. 1263-1272, 2001.

[15]C. Pujiastuti, L. Nofitasari, and F. Erfani, "Kinetika Reaksi Pembentukan Trikalsium Phosphate (Ca3(PO4)2) dari Kalsium Karbonat Berbahan Baku Cangkang Kupang Putih,” J. Reseacrh Technol., vol. 6, no. 1, pp. 137-144, 2020.

[16] A. A. Dinarsari and A. Adhitasari, "Proses Hidrolisa Pati Talas Sente (Alocasia macrorrhiza) menjadi Glukosa : Studi Kinetika Reaksi,” J. Teknol. Kim. dan Ind., vol. 2, no. 4, pp. 253-260, 2013.

[17]M. S. Shalaby and S. El-rafie, "Struvite Precipitation and Phosphorous Removal from Urine Synthetic Solution : Reaction Kinetic Study Struvite Precipitation and Phosphorous Removal from Urine Synthetic Solution : Reaction Kinetic Study,” Bull. Chem. React. Eng. Catal., vol. 10, no. 1, pp. 88-97, 2015.

[18] S. Hamzah, F. Ulum, Sutiyono, and L. Edahwati, "Kinetika Reaksi Pembentukan Pupuk Struvite dari Limbah Cair Tempe Secara Batch,” in Seminar Nasional Soebardjo Brotohardjono XVI, 2020. 